\title{
PERANCANGAN SISTEM INFORMASI E-JURNAL PADA PRODI SISTEM INFORMASI DIUNIVERSITAS ISLAM INDRAGIRI
}

\author{
${ }^{12}$ Fatimah,Samsudin \\ ${ }^{12}$ Program Studi Sistem Informasi, Fakultas Teknik dan Ilmu Komputer \\ Universitas Islam Indragiri (UNISI) \\ J1. Parit 1, Tembilahan Hulu, Tembilahan Riau \\ Ajafatimah10@gmail.Com, Samsudin as.ad@gmail.com
}

\begin{abstract}
ABSTRAK
Mahasiswa / mahasiswi universitas Islam Indragiri saat ini masih kesulitan dalam mencari jurnal - jurnal yang dibutuhkan untuk penulisan skripsi, hal ini mendorong penulis untuk merancang sistem informasi e-jurnal pada prodi sistem informasi atau website online yang nantinya akan dapat membantu pencarian jurnal, metode pengumpulan data yaitu observasi, wawancara, dan quisioner dan model pengembangan sistem ini menggunakan SDLC ( system Developmen life Cycle ), untuk merancang aplikasi ini digunakan perancang struktural yaitu pembuatan contex diagram, data Flow diagram (DFD), Entity Relationship diagram ( ERD ), dalam pembuatan perangkat lunak ini menggunakan PHP sebagai script yang digunakan untuk membuat halaman website dan MYSQL sebagai database yaitu tempat penyimpanan data, dengan adanya e- jurnal ini dapat membantu proses pencarian jurnal - jurnal yang dilakukan oleh mahasiswa, website e- jurnal ini dapat dijadikan media bimbingan jurnal yang dilakukan mahasiswa melalui online, hasil dari sistem ini adalah dapat membantu program studi sistem informasi dalam pelayanan jurnal dan menyajikan jurnal- jurnal, dengan adanya sistem e- jurnal dapat membantu mempermudah mahasiswa dalam proses pencarian jurnal untuk penulisan skripsi.
\end{abstract}

Kata kunci : sistem informasi, e - jurnal, PHP, MYSQL,

\section{PENDAHULUAN}

Kemajuan teknologi informasi yang semakin pesat, mendorong setiap aspek serta dalam peningkatan teknologi informasi tersebut, hal ini juga dilakukan pada universitas - universitas atau lembaga yang bergerak dalam bidang pendidikan. Dalam pendidikan membutuhkan suatu sistem informasi yang terkomputerisasi karena hal ini disebabkan suatu sistem yang terkomputerisasi mempunyai banyak kelebihan dibandingkan dengan sistem manual. Website sebagai contoh penerapan teknologi informasi karena merupakan suatu aplikasi yang dapat memberikan kemudahan untuk memperoleh informasi. Saat ini website tidak asing lagi buat kita, karena banyak digunakan oleh organisasi-organisasi sebagai media atau sarana untuk memperoleh informasi dan memeberikan yang berguna bagi semua pihak yang berkepentingan.

E-Jurnal atau Jurnal elektronik, E-jurnal secara sederhana dapat diartikan sebagai penyampaian informasi dan komunikasi atau jurnal secara online. Karekteristik E-jurnal adalah memanfaatkan teknologi elektroik dimana antara penerbit, penulis dan pembaca dapat saling berkomunikasi, dan memanfaatkan keuunggulan TIK, atau data karya tulis disimpan secara mandiri sehingga dapat diakses dimana saja, kapan saja bila penerbit, penulis dan pembaca memerlukannya.

Universitas Islam Indragiri yang terdiri dari fakultas - fakultas diantaranya fakultas tekhnik dan ilmu komputer khusus nya prodi sistem informasi yang belum mempunyai sistem e-jurnal, dan sistem yang akan dibangun masih menggunakan sistem yang manual, dan kesulitan bagi mahasiswa dalam pencarian jurnal-jurnal yang dibutuhkan dalam penelitian.

Dari beberapa masalah yang terjadi pada prodi sistem informasi di Universitas Islam Indragiri, peneliti tertarik untuk mengangkat judul "PERANCANGAN SISTEM INFORMASI E-JURNAL PADA PRODI SISTEM INFORMASI DI UNIVERSITAS ISLAM INDRAGIRI”. Sistem ini 
diharapkan dapat membantu fakultas teknik dan ilmu komputer khusunya prodi sistem informasi dan mahasiswa dalam pencarian jurnal - jurnal.

Adapun perumusan masalah pada penelitian ini adalah :

1. Universitas islam indragiri khususnya prodi sistem informasi belum mempunyai dan menggunakan sistem E-jurnal.

2. Pencarian jurnal masih sulit karena belum ada sistem E-jurnal tersendiri yang menyediakan jurnal - jurnal.

3. Kesulitan bagi mahasiswa dalam mencari jurnal-jurnal yang dibutuhkan dalam penulisan / pengerjaan Skripsi atau kuliah kerja usaha (KKU)

Batasan masalah dalam penelitian ini adalah :

1. Penelitian ini dilakukan di universitas islam indragiri khususnya fakultas tekhnik dan ilmu komputer yaitu prodi sistem informasi.

2. Aplikasi yang digunakan dalam pembuatan sistem e-jurnal dibuat dengan berbasis web, dengan sofware pengolah yaitu Macromedia Dreamweaver dan MySQL sebagai databasenya.

3. Pengembangan sistem yang digunakan yaitu metode sistem Development Life cycle/ SDLC

4. Sistem informasi e-jurnal ini dapat diakses atau digunakan oleh Prodi, Dosen, Mahasiswa dan Pengguna Lainnya Universitas Islam Indragiri khususnya jurusan prodi sistem informasi.

5. Sampel penelitian ini diambil dari hasil wawancara dan observasi.

Tujuan yang ingin dicapai pada penelitian ini adalah :

1. Untuk menghasilkan sistem E-jurnal yang baru pada prodi sistem informasi.

2. Untuk merancang sebuah sistem E-jurnal yang terkomputerisasi sehingga memudahkan para mahasiswa dalam pencarian jurnal - jurnal.

3. Untuk mengetahui informasi tentang jurnal - juranl terbaru yang dibutuhkan / dicari oleh mahasiswa.

Manfaat yang ingin dicapai pada penelitian ini adalah :

1. Sistem yang telah dibuat dengan terkomputerisasi ini dapat memudahkan para mahasiswa dalam mencari jurnal - jurnal yang dibutuhkan dengan menggunakan aplikasi sistem informasi E-jurnal.

2. Jika data - data jurnal mempunyai sistem tersendiri akan mudah dalam proses pencarian.

3. Mempermudah para mahasiswa, Dosen dan Pengguna Lainnya dalam mengetahui informasi jurnal terbaru.

\section{TINJAUAN PUSTAKA}

Beberapa teori yang digunakan sebagai dasar dalam penelitian ini antara lain teori tentang sistem, informasi, sistem informasi.

\subsection{Sistem}

Jogiyanto (2009) sistem adalah kumpulan dari komponen-komponen yang saling berhubungan satu dengan yang lainnya membentuk satu kesatuan untuk mencapai tujuan tertentu.

\subsection{Pengertian Informasi}

McFaden,dkk (1999) mendefinisikan informasi sebagai data yang telah diproses sedemikian rupa sehingga meningkatkan pengetahuan seseorang yang menggunakan data tersebut. Shannon dan Weaver, dua orang insinyur listrik, melakukan pendekatan secara matematis untuk mendefinisikan informasi (Kroenka,1992). Menurut mereka, informasi adalah "jumlah ketidakpastian yang dikurangi ketika sebuah pesan diterima", artinya dengan adanya informasi tingkat kepastian menjadi meningkat. Menurut Davis (1999), Informasi adalah data yang telah diolah menjadi sebuah bentuk yang berarti bagi sipenerimanya dalam pengambilan keputusan saat ini atau saat mendatang.

\subsection{Sistem Informasi}


Ada beberapa definisi sistem informasi, berdasarkan beberapa defenisi tersebut, dapat disimpulkan bahwa sistem informasi mencakup sejumlah komponen (manusia, komputer, teknologi informasi dan prosedur kerja), ada sesuatu yang diproses (data menjadi informasi), dan dimaksudkan untuk mencapai suatu sasaran atau tujuan. Sistem informasi adalah kombinasi antar prosedur kerja, informasi, orang, dan teknologi informasi yang diorganisasikan untuk mencapai tujuan dalam sebuah organisasi (Alter,1992).

Sistem informasi adalah kumpulan perangkat keras dan perangkat lunak yang dirancang untuk mentransformasikan data kedalam bentuk informasi yang berguna (Bodnar dkk,1993).

Sistem informasi adalah suatu sistem buatan manusia yang secara umum terdiri dari sekumpulan komponen berbasis komputer dan manual yang dibuat untuk menghimpun, menyimpan, dan mengelola data serta menyediakan informasi keluaran kepada para pemakai (Gelins dkk,1990).

Sistem informasi adalah sebuah rangkaian prosedur formal dimana data dikelompokan, diproses menjadi informasi, dan didistribusikan kepada pemakai (Hall,2001).

Sistem informasi mengumpulkan, memproses, menyimpan, menganalisa, dan menyebarkan informasi untuk tujuan yang spesifik (Turban dkk, 1999).

Sistem informasi adalah kerangka kerja yang mengoordinasikan sumber daya (manusia, komputer) untuk mengubah masukan (input) menjadi keluaran (informasi), guna mencapai sasaran - sasaran perusahaan (Wilkinson,1992).

\subsection{Model Pengembangan Sistem}

Model pengembangan sistem yang digunakan dalam penelitian saya ini menggunakan SDLC ( System Development Life Cycle ). Menurut Jogianto (2009) siklus hidup pengembangan sistem mempunyai beberapa tahapan, sesuai namanya SDLC dimulai dari suatu tahapan sampai akhir dan kembali lagi ketahapan awal membentuk siklus .

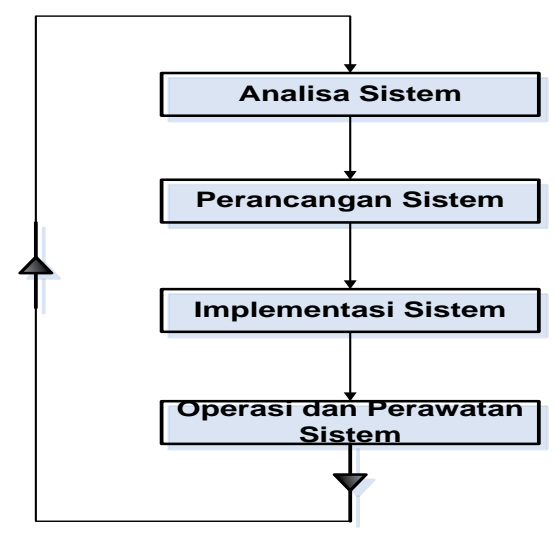

\section{Gambar 1 Tahapan Siklus Pengembangan sistem}

\subsection{Konsep Pemodelan Sistem}

\subsubsection{Bagan Alir Dokumen}

Menurut Jogiyanto,Bagan aliran dokumen berbeda dengan bagan alir program (program flowchart). Bagan alir program sifatnya lebih terperinci tentang langkah-langkah proses didalam program dari awal sampai akhir

\subsubsection{Contex Diagram}

Menurut Jogiyanto dalam Zefriyenni (2015)Context Diagram adalah gambaran umum tentang suatu sistem yang terdapat didalam suatu organisasi yang memperlihatkan batasan (boundary) sistem, adanya interaksi antara eksternal entity dengan suatu sistem dan informasi secara umum mengalir diantara entity dan sistem. 


\subsubsection{Data Flow Diagram (DFD)}

Menurut Hartono (1999), Data Flow Diagram (DFD) adalah diagram yang menggunakan notasi simbol untuk menggambarkan arus data sistem. Kita dapat menggunakan DFD untuk dua hal utama yaitu untuk membuat dokumentasi dari sistem informasi yang ada, atau untuk menyusun dokumentasi untuk sistem informasi yang baru.

\subsection{Konsep Basis Data}

\subsubsection{Entity Relationship Diagram (ERD)}

Menurut Susanta $(2004,79)$ menyatakan bahwa ERD berguna untuk memodelkan sistem yang nantinya akan dikembangkan basis datanya.

\subsection{Software Yang Digunakan}

\subsubsection{Pengertian Internet}

Menurut Jasmadi \& Purwadi Internet adalah sebagai jaringan komputer yang sangat luas dan besar dan mendunia, menghubungkan pemakai komputer dari satu negara ke negara lain di seluruh dunia,dimana di dalamnya terdapat berbagai sumber informasi

\subsubsection{Pengertian Website}

Website adalah suatu halaman yang memuat situs-situs web page yang berada di internet yang berfungsi sebagai media penyampaian informasi, komunikasi, atau transaksi (Hastanti, 2015).

\subsubsection{Pengertian Browsing}

Menurut Jasmadi dalam Hastanti (2015) Browsing dalam adalah Berselancar untuk menjelajahi informasi yang ada di internet. Browsing dapat juga diartikan seni pencarian informasi melalui system operasi yang berbasis hypertext, misalnya membaca berita, mencari istilah dan lain-lain.

\subsubsection{Pengertian Browser}

browser adalah sebuah perangkat lunak atau software yang berfungsiuntuk menampilkan dan melakukan interaksi dengan dokumen-dokumen yang disediakan oleh server web.

\subsubsection{Pengertian PHP}

Menurut Hariadi dkk (2013).PHP adalah bahasa pemrograman web atau scripting language yang dijalankan diserver, PHP adalah sekumpulan script yang digunakan untuk mengolah data form dari web.

\subsubsection{Pengertian HTML}

Menurut Hariadi dkk (2013).HTML (Hypertext Markup Language)adalah sebuah bahasa pemrograman yang berbentuk skrip-skrip yang berguna untuk membuat sebuah halaman web.

\subsubsection{Pengertian Macromedia Dreamweaver}

Menurut Hariadi dkk (2013). Dreamweaver 8 adalah suatu bentuk program editor web yang dibuat oleh Macromedia. Dengan menggunakan programini, seorang programmer web dapat denganmudah membuat dan mendesain webnya, karena bersifat WYSIWYG (What You See Is What You Get).

\subsubsection{Pengertian MYSQL}

SQL adalah sebuah konsep pengoperasian basis data, terutama untuk pemilihan atau seleksi dan pemasukkan data, yang memungkinkan pengoperasian data dikerjakan dengan mudah secara otomatis.(Sengkey, 2015).

\subsubsection{Pengertian XAMPP}

XAMPP adalah perangkat lunak bebas, yang mendukung banyak system operasi, merupakan kompilasi dari beberapa program. Fungsinya adalahsebagai server yang berdiri sendiri (localhost), yang terdiri atas program Apache HTTP Server, MySQL database, dan penerjemah bahasa yang ditulis dengan bahasa pemrograman PHP dan Perl.

\subsubsection{Pengertian CSS}

Cascading Style Sheet (CSS) merupakan aturan untuk mengendalikan beberapa komponen dalam sebuah web sehingga akan lebih terstruktur dan seragam. CSS bukan merupakan bahasa pemograman. Pada umumnya CSS dipakai untuk memformat tampilan halaman web yang dibuat dengan bahasa HTML dan XHTML. (Sengkey, 2015)

\subsection{PengujiAn sistem \\ 2.8.1 Blackbox Testing}


Black Box Testing berfokus pada spesifikasi fungsional dari perangkat lunak. Tester dapat mendefinisikan kumpulan kondisi input dan melakukan pengetesan pada spesifikasi fungsional program. Black Box Testing bukanlah solusi alternatif dari White Box Testing tapi lebih merupakan pelengkap untuk menguji hal-hal yang tidak dicakup oleh White Box Testing (Mustaqbal, 2015)

\subsubsection{Whitebox Testing}

Nidhra \& Dondetti dalam Mustaqbal(2015)White Box Testing adalah salah satu cara untuk menguji suatu aplikasi atau software dengan cara melihat modul untuk dapat meneliti dan menganalisa kode dari program yang di buat ada yang salah atau tidak.

\section{METODE PENELITIAN}

Dalam menganalisa suatu sistem diperlukan data-data, untuk mengambil data maka dilakukan teknik pengumpulan data untuk keperluan penelitian sebagai berikut:

a. Observasi ( observation )

Teknik pengumpulan data dengan melakukan pengamatan dan penelitian secara langsung apakah sistem yang diteliti ada atau tidak di prodi sistem informasi tersebut

b. Wawancara ( Interview)

Teknik pengumpulan data yang dilakukan melalui tatap muka dan mengadakan tanya jawab secara langsung antara peneliti dengan prodi sistem informasi di universitas islam indragiri.

c. Studi literatur

Teknik yang menggunakan buku - buku atau artikel - artikel lain yang dapat membantu permasalahan untuk menyelesaikan masalah yang dapat dipakai sebagai landasan teori.

\section{HASIL DAN PEMBAHASAN}

\section{Perancangan Proses}

Perancangan proses menguraikan pemodelan proses sistem yang dibuat. Tujuan perancangan proses untuk menjaga dan teratur sehingga menghasilkan informasi yang benar diantaranya Contex Diagram, Data Flow Diagram,Entity Realationship Diagram

\section{Conteks Diagram}

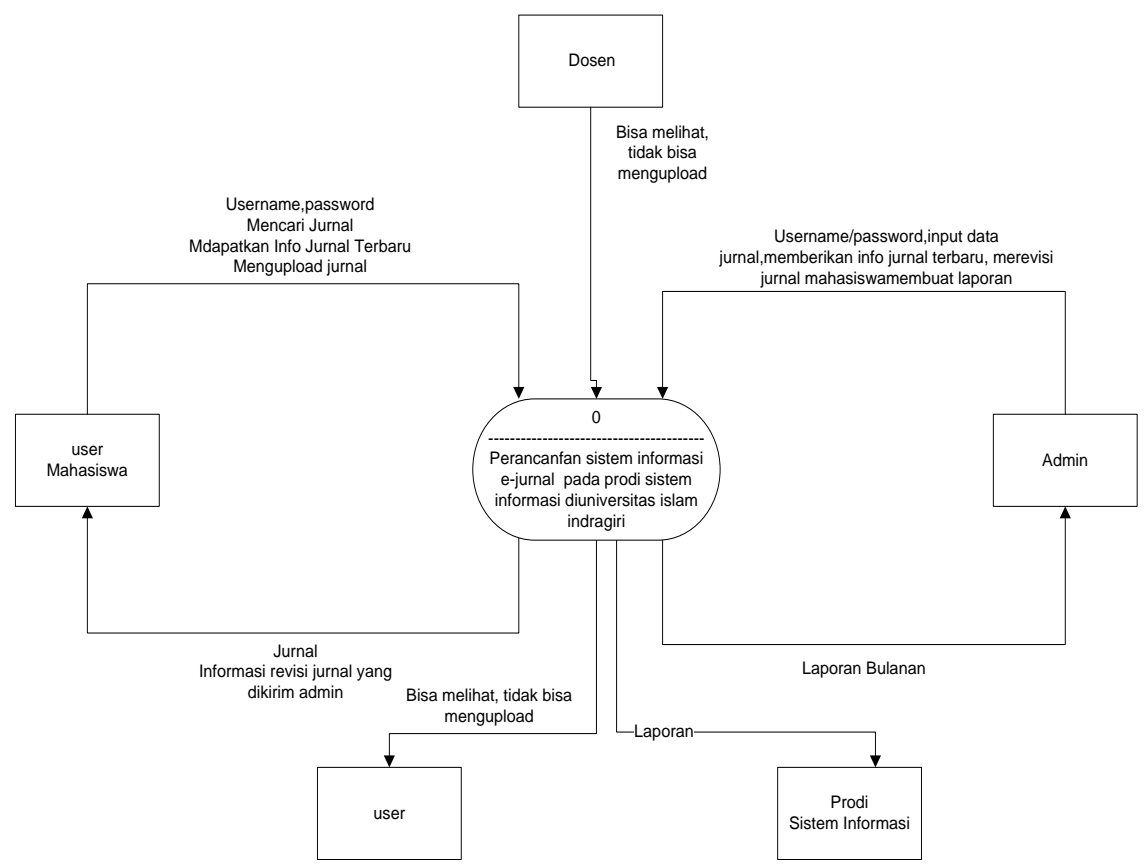

Gambar 2 contex Diagram 


\section{Data Flow Diagram}

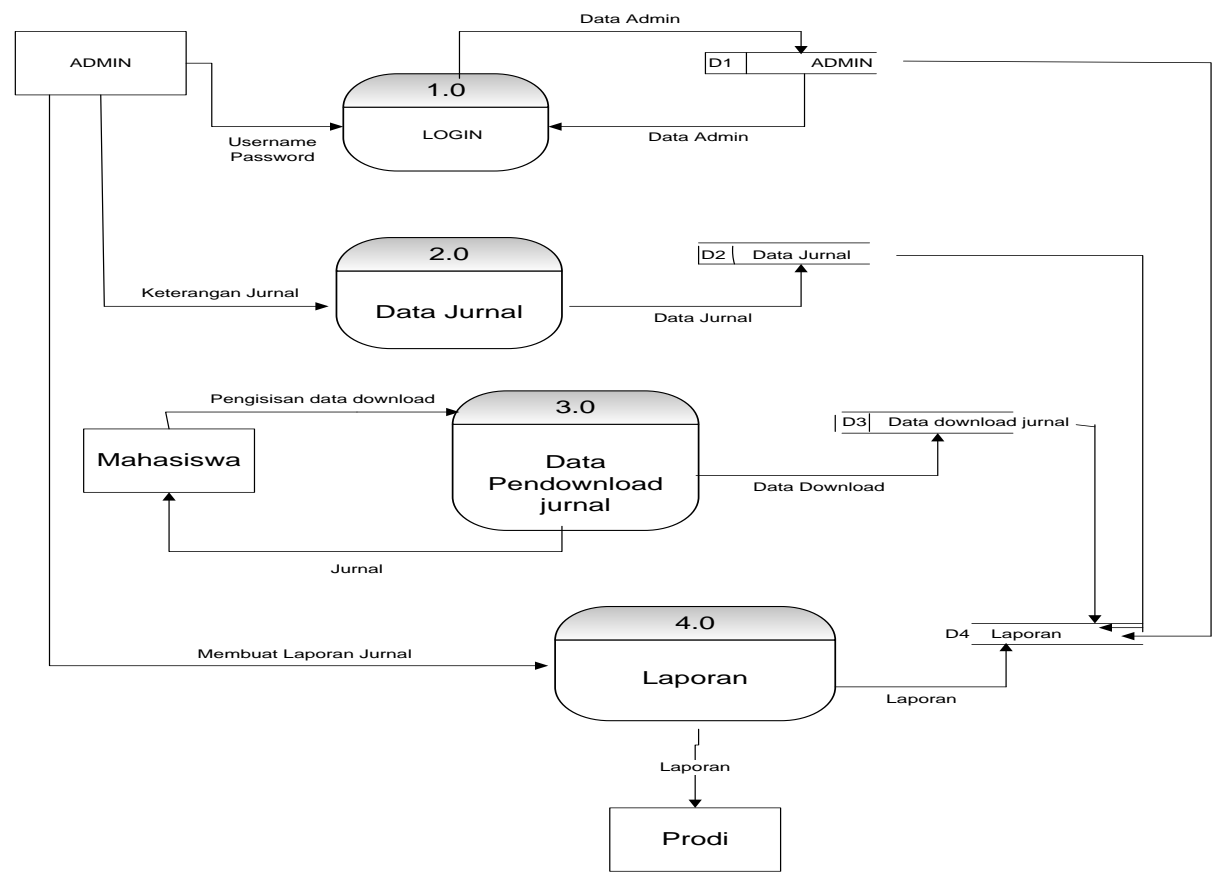

Gambar 3 Data Flow Diagram

\section{Entity Relationship Diagram}

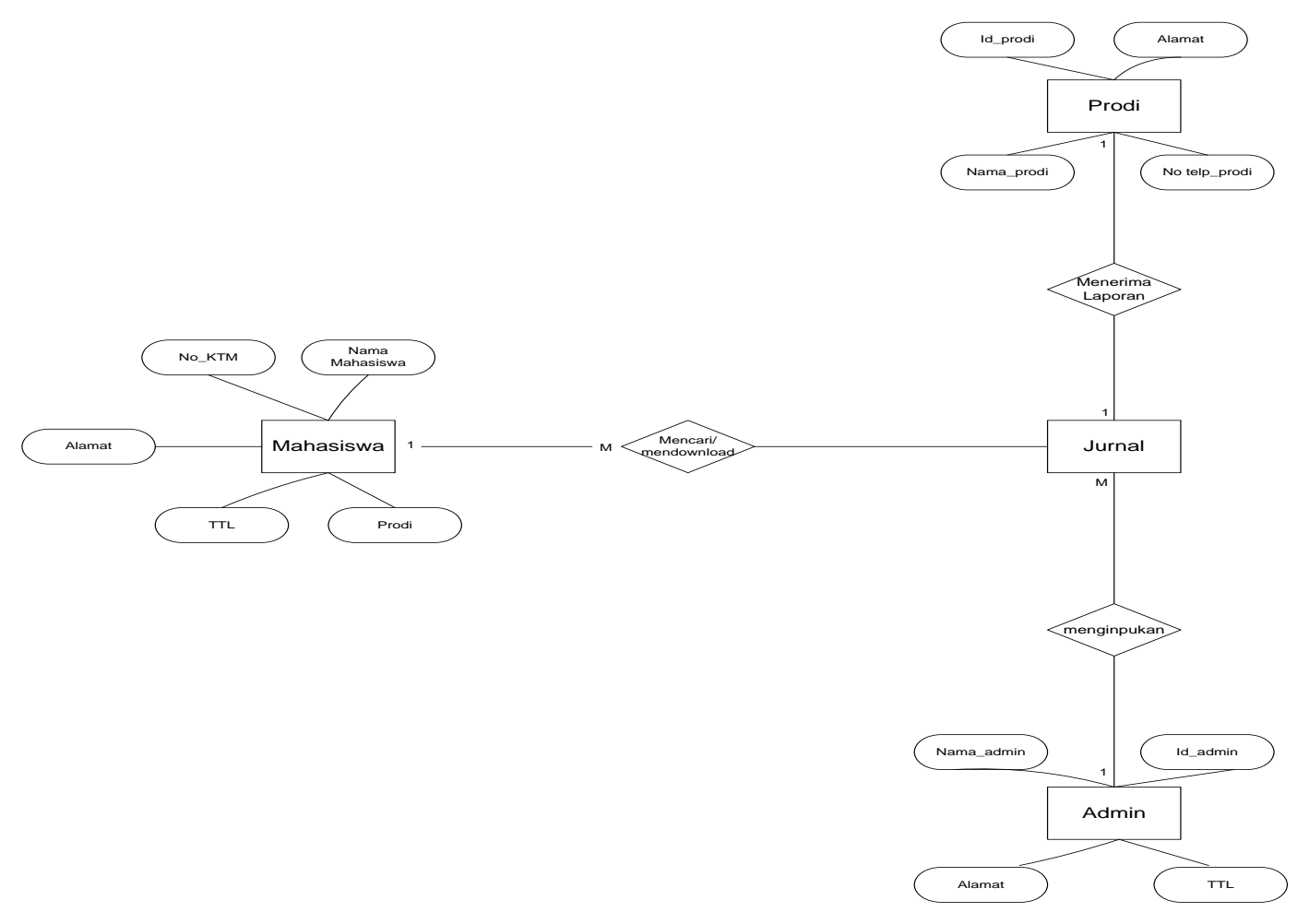

Gambar 4 Entity Relationship Diagram

\section{Form Menu Utama}


Form menu utama merupakan form yang akan muncul apabila user dan admin membuka halaman web seperti yang terdapat pada gambar 5

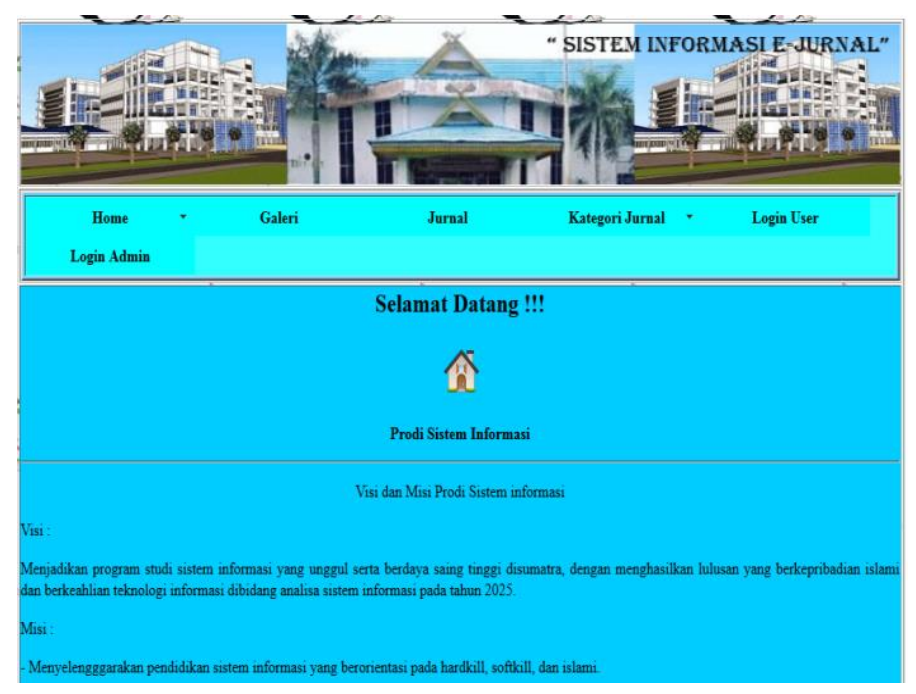

Gambar 5 : menu Utama

Pada form menu utama terdapat lima buah menu yaitu Home, Galeri, Jurnal, Kategori jurnal, Login user, Login Admin, yang berfungsi untuk menampilkan form yang akan di panggil.

\section{Form Menu Galeri}

Form menu galeri merupakan form yang akan muncul apabila user dan admin mengklik dan akan timbul gambar - gambar yang berkaitan dengan prodi sistem informasi seperti yang terdapat pada gambar 6

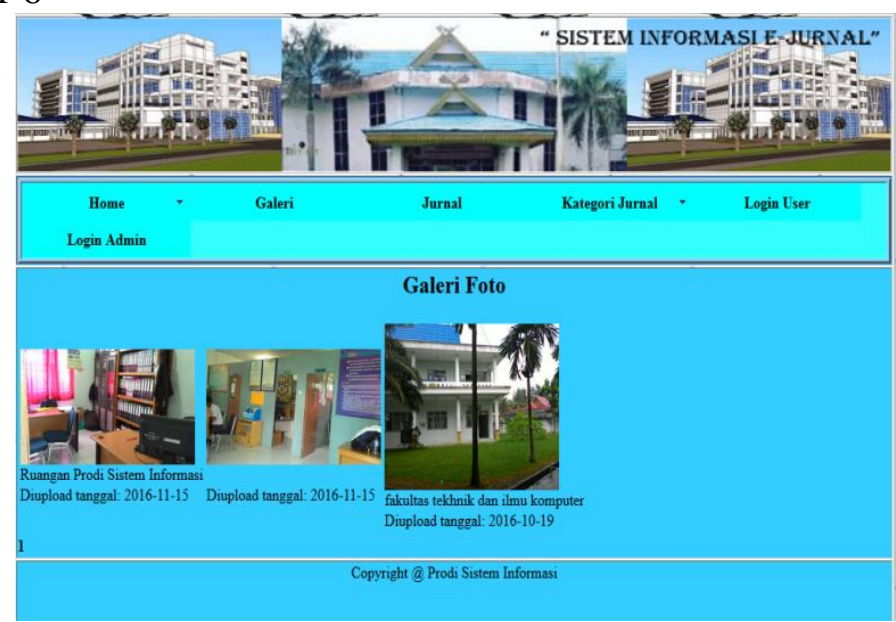

\section{Gambar 6 : Menu Galeri}

Pada form menu Galeri yaitu tempat untuk menampilkan gambar - gambar atau foto foto berkaitan dengan prodi sistem informasi yang bisa di lihat oleh user.

\section{Form Menu Jurnal}

Form menu jurnal merupakan form yang akan menampilkan kumpulan jurnal - jurnal yang dapat membantu user dalam mencari jurnal yang dibutuhkannya, seperti yang terdapat pada gambar 7 


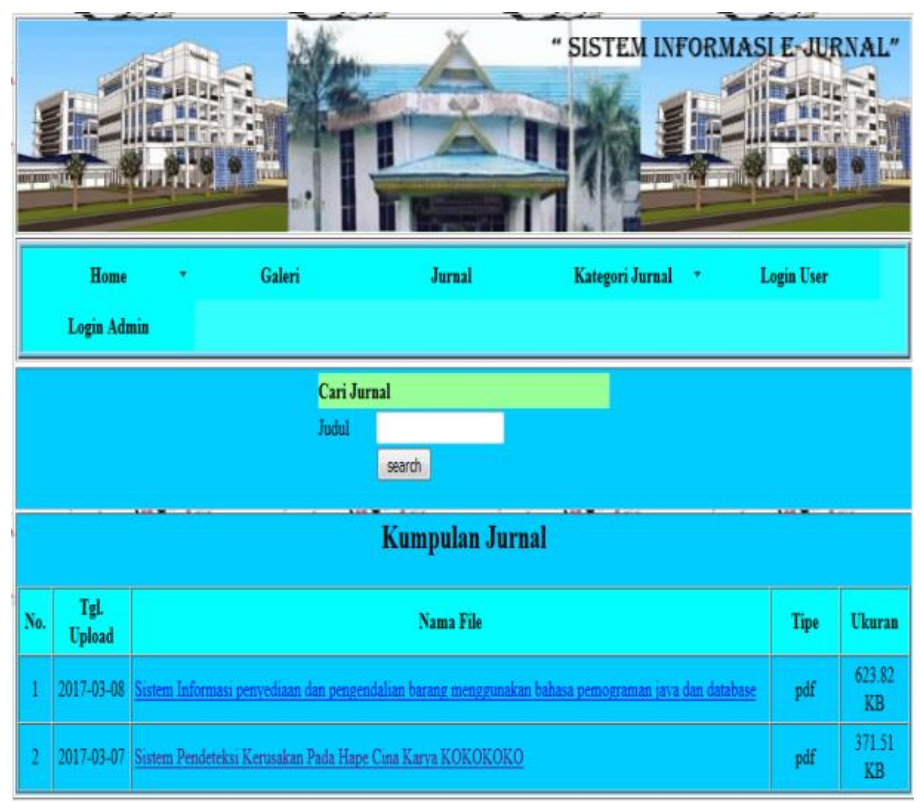

Gambar 7 : Menu Jurnal

Pada form menu Jurnal yaitu tempat untuk menampilkan kumpulan jurnal- jurnal yang bisa di lihat oleh user dan di download oleh User.

\section{Form Menu Kategori Jurnal}

Form menu Kategori jurnal merupakan form jurnal yang sudah dikategori misalnya seperti jurnal sistem informasi diklik dan akan muncul semua jurnal sistem informasi yang sudah dimasukkan oleh admin, seperti yang terdapat pada gambar 8

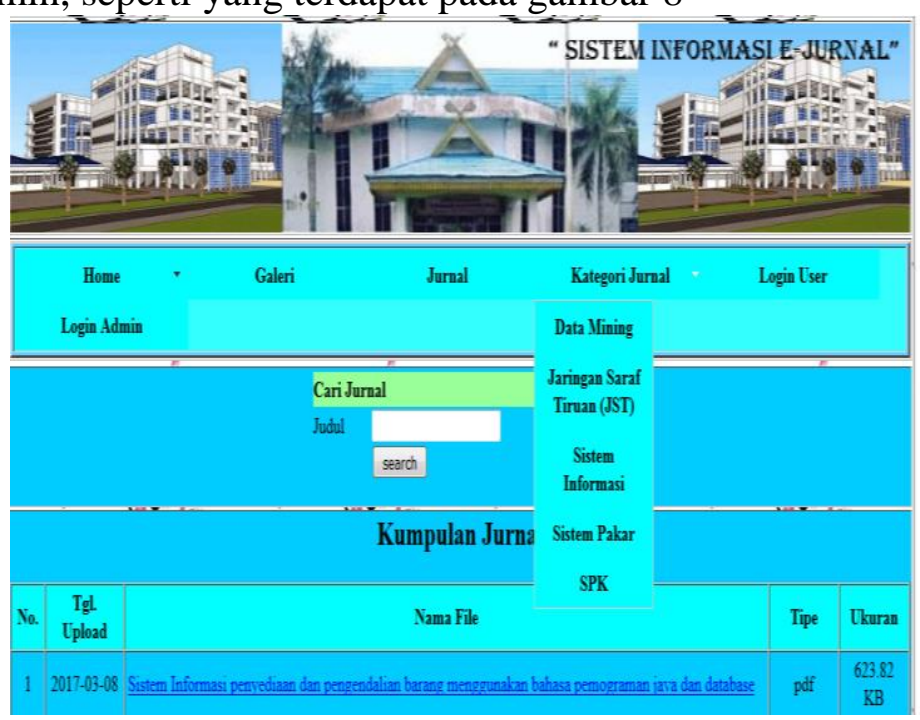

Gambar 8 Menu kategori jurnal

Pada form menu kategori Jurnal yaitu terdiri dari kategori sistem informasi, data mining, jaringan saraf tiruan, sistem pakar, sistem pendukung keputusan.

\section{Form Menu Login User}

Form login user adalah form yang digunakan untuk masuk ke form menu user, Berikut adalah tampilan gambar 9 form login user : 


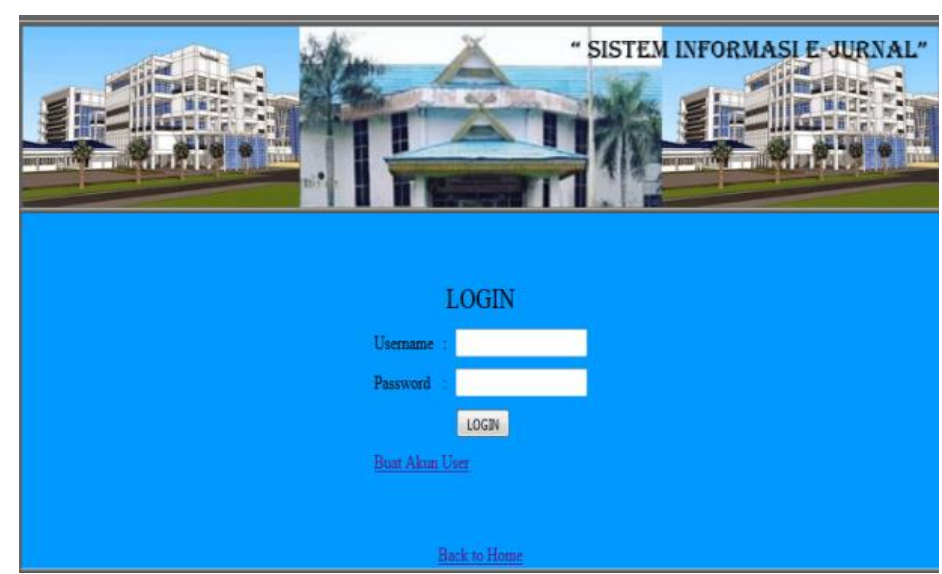

Gambar 9 : Menu Login User

Pada form ini user dapat login dengan menginputkan username dan password secara benar sesuai dengan yang sudah dibuat oleh user, Jika username dan password benar maka akan tampil form user untuk menjalankan aplikasi.

\section{Form Menu Login Admin}

Form login admin adalah form yang digunakan untuk masuk ke form menu admin, Berikut adalah tampilan gambar 10 form login admin :

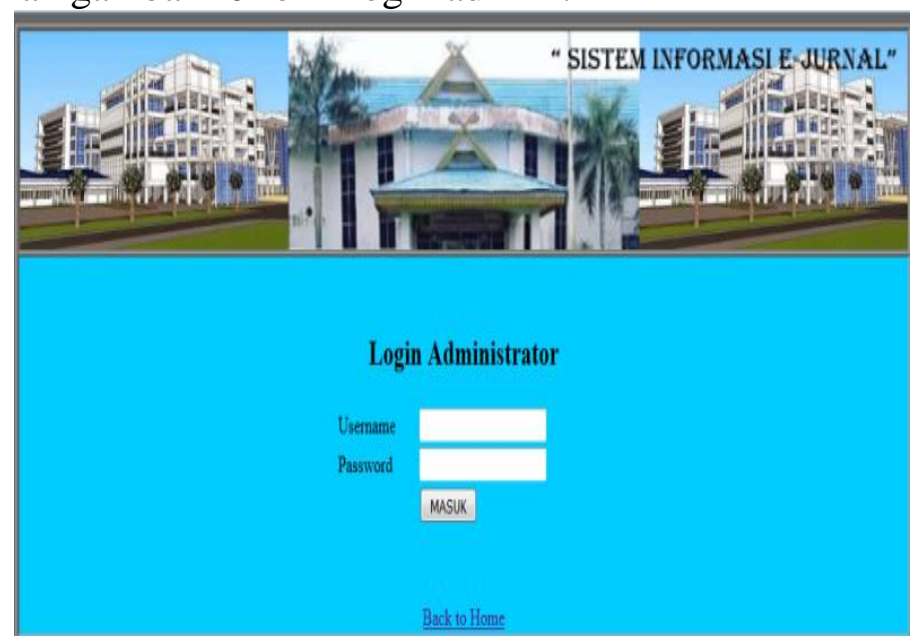

\section{Gambar 10 : Login Admin}

Pada form ini admin dapat login dengan menginputkan username dan password secara benar sesuai dengan yang sudah yang ada di database, Jika username dan password benar maka akan tampil form admin untuk menjalankan aplikasi.

\section{Laporan}

Form laporan merupakan form yang akan menampilkan laporan yang telah diupload oleh user, seperti yang terdapat pada gambar 11 


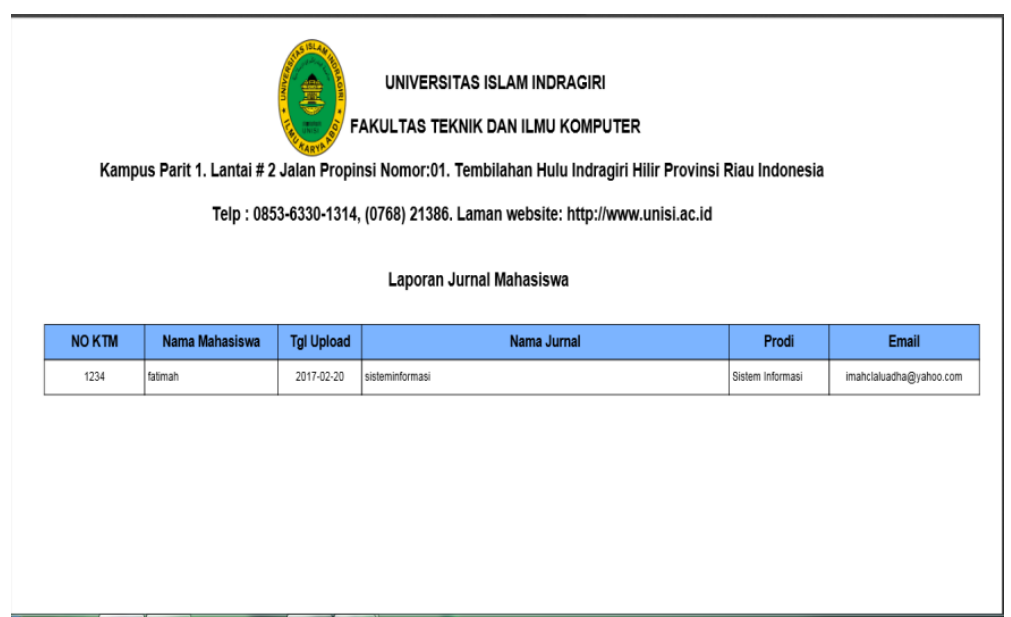

Gambar 11 : Laporan Jurnal Mahasiswa

Pada from laporan yaitu tampilan laporan upload jurnal mahasiswa, apabila mahsiswa mengupload dan masuk langsung kedalam laporan.

\section{Pengujian Black box}

Berikut adalah pengujian form upload jurnal mahasiswa dengan menggunakan metode blackbox dapat dilihat pada tabel 1 adalah sebagai berikut:

Tabel 1 Pengujian upload jurnal mahasiswa

\begin{tabular}{|c|c|c|c|c|}
\hline Di Uji & Di Inputkan & Diharapkan & Kenyataan & Keterangan \\
\hline Nim & $\begin{array}{l}\text { Nim (Huruf) } \\
\text { Nim (Angka) }\end{array}$ & Tersimpan & Tidak tersimpan & $\left\{\begin{array}{l}\sqrt{ }\} \\
\{\}\end{array}\right.$ \\
\hline Nim & $\begin{array}{l}\text { Nim (Angka) } \\
\text { Nim (Huruf) }\end{array}$ & Tersimpan & Tidak tersimpan & $\left\{\begin{array}{l}\sqrt{ }\} \\
\{\}\end{array}\right.$ \\
\hline Nim & Nim (Huruf) & Tersimpan & Tidak tersimpan & $\{\sqrt{ }\}$ \\
\hline Nim & Nim ( Angka) & Tersimpan & Tersimpan & $\{\sqrt{ }\}$ \\
\hline Nama MHS & $\begin{array}{l}\text { Nama (Huruf) } \\
\text { Nama (angka) }\end{array}$ & Tersimpan & Tidak tersimpan & $\begin{array}{l}\left\{\begin{array}{l}1 \\
\{ \\
\{\quad\}\end{array}\right.\end{array}$ \\
\hline Nama MHS & $\begin{array}{l}\text { Nama (Angka) } \\
\text { Nama (Huruf) }\end{array}$ & Tersimpan & Tidak tersimpan & 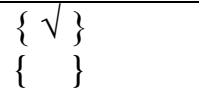 \\
\hline Nama MHS & Nama ( Huruf) & Tersimpan & Tersimpan & $\begin{array}{l}\{\sqrt{ }\} \\
\{\}\end{array}$ \\
\hline Nama MHS & Nama (Angka) & Tersimpan & Tidak tersimpan & $\begin{array}{l}\{\sqrt{ }\} \\
\{\}\end{array}$ \\
\hline Prodi & $\begin{array}{l}\text { Prodi (Huruf) } \\
\text { Prodi (Angka) }\end{array}$ & Tersimpan & Tidak tersimpan & $\{\sqrt{ }\}$ \\
\hline Prodi & $\begin{array}{l}\text { Prodi (Angka) } \\
\text { Prodi (Huruf) }\end{array}$ & Tersimpan & Tidak tersimpan & 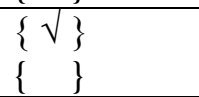 \\
\hline Prodi & Prodi (Huruf) & Tersimpan & Tersimpan & $\begin{array}{l}\{\sqrt{ }\} \\
\{\quad\}\end{array}$ \\
\hline Prodi & Prodi (Angka) & Tersimpan & Tidak tersimpan & $\{\sqrt{ }\}$ \\
\hline Email & $\begin{array}{l}\text { Email (Huruf) } \\
\text { Email (Angka) }\end{array}$ & Tersimpan & Tersimpan & 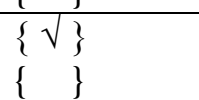 \\
\hline
\end{tabular}




\begin{tabular}{|l|l|l|l|l|}
\hline Email & $\begin{array}{l}\text { Email (Angka) } \\
\text { Email (Huruf) }\end{array}$ & Tersimpan & Tersimpan & $\begin{array}{l}\{\sqrt{ }\} \\
\{,\}\end{array}$ \\
\hline Email & Email (Huruf) & Tersimpan & Tidak tersimpan & $\begin{array}{l}\{\sqrt{ }\} \\
\{,\end{array}$ \\
\hline Email & Email (Angka) & Tersimpan & Tidak tersimpan & $\begin{array}{l}\{\sqrt{ }\} \\
\{\}\end{array}$ \\
\hline Nama file & $\begin{array}{l}\text { Nama (Huruf) } \\
\text { Nama (angka) }\end{array}$ & Tersimpan & Tidak tersimpan & $\begin{array}{l}\{\sqrt{ }\} \\
\{\}\end{array}$ \\
\hline Nama file & $\begin{array}{l}\text { Nama (Angka) } \\
\text { Nama (Huruf) }\end{array}$ & Tersimpan & Tidak tersimpan & $\begin{array}{l}\{\sqrt{ }\} \\
\{\}\end{array}$ \\
\hline Nama file & Nama (Huruf) & Tersimpan & Tersimpan & $\begin{array}{l}\{\sqrt{ }\} \\
\{\end{array}$ \\
\hline Nama file & Nama (Angka) & Tersimpan & Tidak tersimpan & $\begin{array}{l}\{\sqrt{ }\} \\
\{\}\end{array}$ \\
\hline $\begin{array}{l}\text { Tombol } \\
\text { Upload }\end{array}$ & $\begin{array}{l}\text { Klik Tombol } \\
\text { Upload }\end{array}$ & Terupload & Upload jurnal & $\begin{array}{l}\{\sqrt{ }\} \\
\text { Berhasil }\end{array}$ \\
\hline
\end{tabular}

\section{Pengujian whitebox (Flowgraph)}

Berikut adalah flowchart dan alur logika upload jurnal mahasiswa sistem informasi e-jurnal pada prodi sistem informasi di Universitas Islam Indragiri, yaitu: 


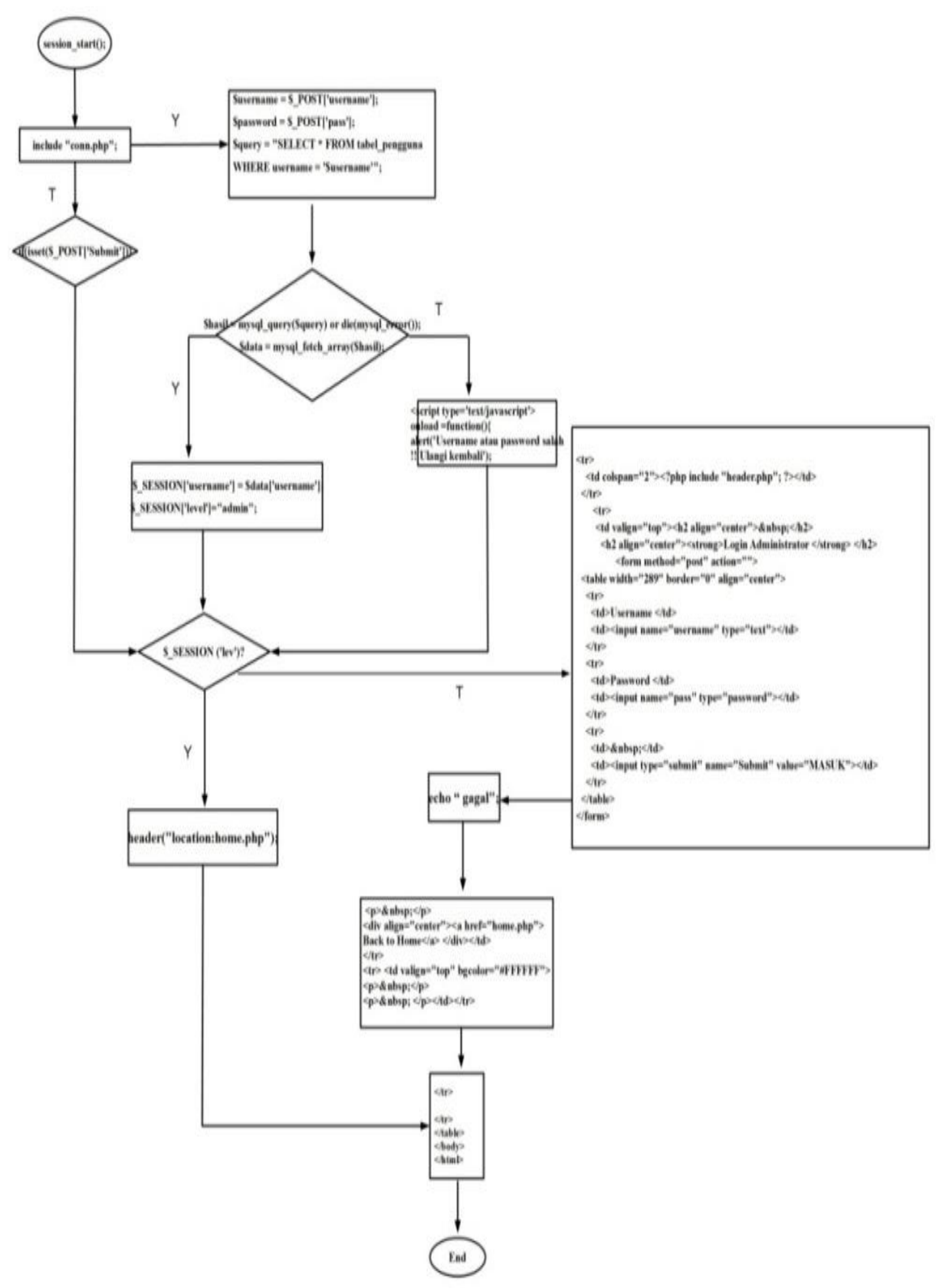

Gambar 12 Alur Flow Graph Login Admin

Berdasarkan alur logika tersebut, maka flowgrafh login admin dapat dilihat pada gambar 13 berikut: 


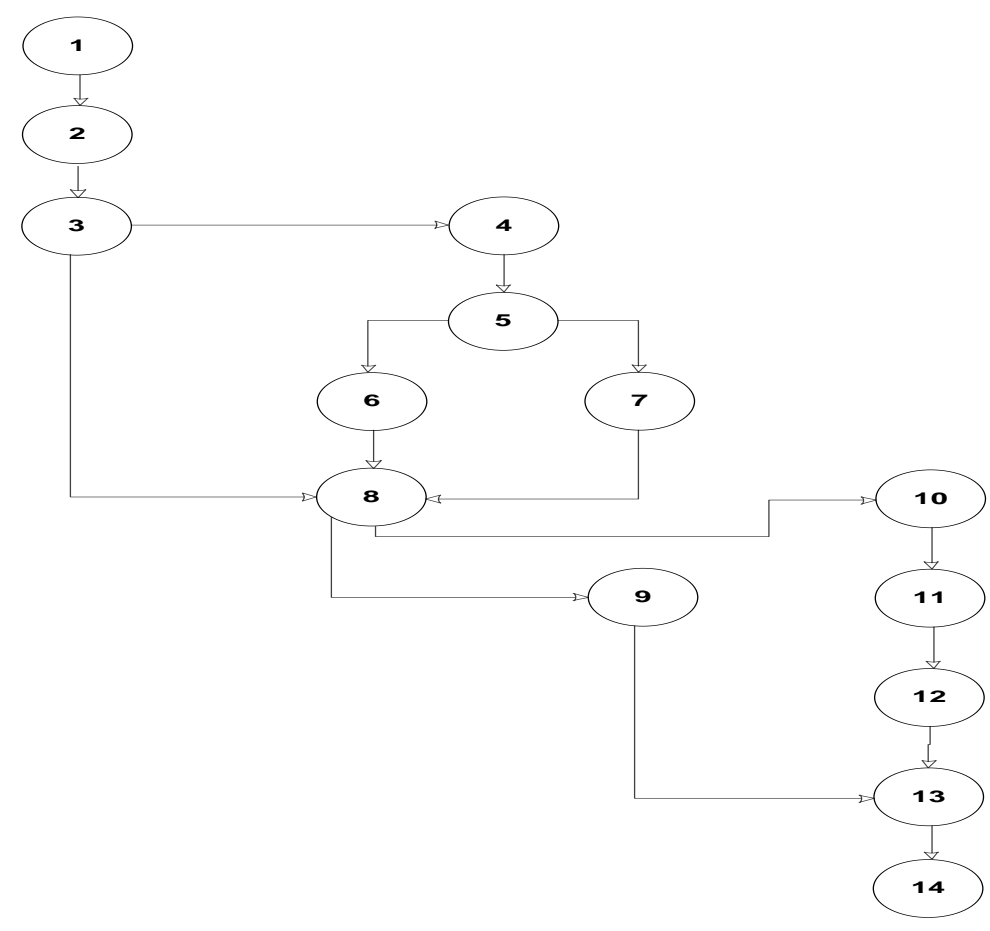

\section{Gambar 13 Flow Graph Login Admin}

Penyelesaian:

Cyclomatic complexity $=$ Jumlah edges - Jumlah nodes +2

$$
\begin{aligned}
& =16-14+2 \\
& =4
\end{aligned}
$$

$\mathrm{V}(\mathrm{G})=$ jumlah region

$=4$

$\mathrm{V}(\mathrm{G}) \quad=\mathrm{E}-\mathrm{N}+2$

$=16-14+2$

$=4$

$\mathrm{V}(\mathrm{G}) \quad=\mathrm{P}+1$

$=3+1=4$

Jalur Independen :

Berikut adalah jalur independen pada Flow Graph Login Admin :
a) $1,2,3,4,5,7,8,10,11,12,13,14$
b) $1,2,3,8,9,13,14$
c) $1,2,3,4,5,6,8,10,11,12,13,14$
d) $1,2,3,4,5,6,8,9,11,12,13,14$

Pada metode white box login admin dapat diketahui bahwa alur program yang membentuk flowgraph terdapat jumlah region 4 , jumlah busur 16 , jumlah simpul 14 , jumlah path 4 dan alur independen path 4.

Dengan hasil pengujian tersebut dengan menggunakan metode white box pada kode program login admin, maka dapat di ambil kesimpulan bahwa login admin tersebut tidak mengalami error atau valid.

\section{Pengujian SPSS}


Adapun pengujian spss yang dapat dilakukan dalam pembuatan sistem informasi e-jurnal pada prodi sistem informasi di Unisi, pengujian yang dilakukan dengan cara menyebarkan angket kuisioner dan disebarkan ke Mahasiswa/i di prodi sistem informasi, yang diambil data dari 20 mahasiswa/i untuk mengetahui kelayakan pembuatan sistem informasi e-jurnal tersebut. Setiap mahasiswa/i diberikan 6 pertanyaan yang sesuai dengan rumusan masalah yang ada di BAB 1, apakah dia sangat setuju, setuju, ragu ragu, tidak setuju atau sangat tidak setuju dengan adanya sistem informasi e-jurnal.

\section{IMPLEMENTASI DAN DAN PENGUJIAN SISTEM 4.4.3.1 Data quisioner}

Tabel 2 Hasil Pengujian quisioner

\begin{tabular}{|c|c|c|c|c|c|c|c|}
\hline \multirow[t]{2}{*}{ No } & \multirow[t]{2}{*}{ Pertanyaan } & \multicolumn{6}{|c|}{$\begin{array}{l}\text { Sangat setuju : } 5 \\
\text { Setuju } \quad: 4 \\
\text { Ragu - ragu }: 3 \\
\text { Tidak setuju }: 2 \\
\text { Sangat tidak setuju : } 1\end{array}$} \\
\hline & & SS & $\mathbf{S}$ & RR & TS & STS & Total \\
\hline 1 & $\begin{array}{l}\text { Jika ada yang membuat website e- } \\
\text { jurnal di program Sistem Informasi } \\
\text { pada Universitas Islam Indragiri } \\
\text { gimana menurut mahasiswa }\end{array}$ & 6 & 14 & - & - & - & 20 \\
\hline 2 & $\begin{array}{l}\text { Menyediakan e-jurnal ( jurnal yang } \\
\text { bisa diunduh secara online ) di program } \\
\text { Sistem Informasi yang bisa didapatkan } \\
\text { oleh mahasiswa / mahasiswi. }\end{array}$ & 8 & 11 & - & 1 & - & 20 \\
\hline 3 & $\begin{array}{l}\text { Membuat sistem yang lebih mudah } \\
\text { dalam hal pencarian jurnal. }\end{array}$ & 6 & 14 & - & - & - & 20 \\
\hline 4 & $\begin{array}{l}\text { Menyediakan tempat jurnal pada } \\
\text { program Sistem Informasi di } \\
\text { Universitas Islam Indragiri dengan } \\
\text { sistem yang berbasis web. }\end{array}$ & 4 & 16 & - & - & - & 20 \\
\hline 5 & $\begin{array}{l}\text { Memberikan kemudahan kepada } \\
\text { mahasiswa/mahasiswi untuk } \\
\text { mengakses jurnal }\end{array}$ & 10 & 10 & - & - & - & 20 \\
\hline 6 & $\begin{array}{l}\text { Website e-jurnal menampilkan dan } \\
\text { memaparkan jurnal jurnal yang } \\
\text { dibutuhkan dalam pengerjaan skripsi }\end{array}$ & 7 & 13 & - & - & - & 20 \\
\hline
\end{tabular}

\section{Correlations}

\section{Tabel 3 Correlations}




\begin{tabular}{|c|c|c|c|c|c|c|}
\hline & & VAR00001 & VAR00002 & VAR00003 & VAR00004 & VAR00005 \\
\hline VAR00001 & Pearson Correlation & 1 & -.019 & .048 & $.764^{* *}$ & .218 \\
\hline & Sig. (2-tailed) & & .936 & .842 & .000 & .355 \\
\hline & $\mathrm{N}$ & 20 & 20 & 20 & 20 & 20 \\
\hline VAR00002 & Pearson Correlation & -.019 & 1 & -.210 & .131 & -.437 \\
\hline & Sig. (2-tailed) & .936 & & .375 & .582 & .054 \\
\hline & $\mathrm{N}$ & 20 & 20 & 20 & 20 & 20 \\
\hline VAR00003 & Pearson Correlation & .048 & -.210 & 1 & .218 & .218 \\
\hline & Sig. (2-tailed) & .842 & .375 & & .355 & .355 \\
\hline & $\mathrm{N}$ & 20 & 20 & 20 & 20 & 20 \\
\hline VAR00004 & Pearson Correlation & $.764^{* *}$ & .131 & .218 & 1 & .250 \\
\hline & Sig. (2-tailed) & .000 & .582 & .355 & & .288 \\
\hline & $\mathrm{N}$ & 20 & 20 & 20 & 20 & 20 \\
\hline VAR00005 & Pearson Correlation & .218 & -.437 & .218 & .250 & 1 \\
\hline & Sig. (2-tailed) & .355 & .054 & .355 & .288 & \\
\hline & $\mathrm{N}$ & 20 & 20 & 20 & 20 & 20 \\
\hline VAR00006 & Pearson Correlation & -.023 & $-.449^{*}$ & -.023 & -.105 & $.524^{*}$ \\
\hline & Sig. (2-tailed) & .924 & .047 & .924 & .660 & .018 \\
\hline & $\mathrm{N}$ & 20 & 20 & 20 & 20 & 20 \\
\hline VAR00007 & Pearson Correlation & $669^{* *}$ & .067 & .418 & $.767^{* *}$ & $.614^{* *}$ \\
\hline & Sig. (2-tailed) & .001 & .779 & .066 & .000 & .004 \\
\hline & $\mathrm{N}$ & 20 & 20 & 20 & 20 & 20 \\
\hline
\end{tabular}


${ }^{* *}$. Correlation is significant at the 0.01 level (2-tailed).

*. Correlation is significant at the 0.05 level (2-tailed).

\subsubsection{Model Summery}

Tabel 5 Model Summery

Case Processing Summary

\begin{tabular}{|ll|l|l|}
\hline & & $\mathrm{N}$ & $\%$ \\
\hline Cases & Valid & 20 & 100.0 \\
& Excluded $^{\mathrm{a}}$ & 0 & .0 \\
& Total & 20 & 100.0 \\
\hline
\end{tabular}

a. Listwise deletion based on all variables in the procedure.

\section{Realibility Statistic}

Tabel 6 Realibility Statistic

\section{Reliability Statistics}

\begin{tabular}{|l|l|}
\hline $\begin{array}{l}\text { Cronbach's } \\
\text { Alpha }\end{array}$ & N of Items \\
\hline .637 & 7 \\
\hline
\end{tabular}

Keterangan :

Dari hasil uji reliabilitas, yang dilihat adalah nilai cronbach's alpha nilai cronbchh's Alpha yang kita peroleh sebesar 0,637 artinya kuesioner yang kita buat sudah reliabel karenaLebih besar dari nilai 0,70 .

\section{KESIMPULAN}

Beberapa hal yang dapat disimpulkan dari penelitian skripsi ini adalah sebagai berikut:

1. Sistem ini dapat membantu Program studi sistem informasi dalam pelayanan tentang jurnal mahasiswa dan menyajikan jurnal - jurnal.

2. Dengan adanya sistem e-jurnal ini daapat membantu mempermudah mahasiswa/mahasiswi dalam proses pencarian jurnal.

3. Jika adanya sistem ini maka mahasiswa/mahsiswi akan mudah mendapatkan jurnal untuk penulisan / pengerjaan karya ilmiah seperti skripsi,

\section{Saran}

Pada umumnya peneliti sangat mengharapkan penelitian ini dapat bermanfaat bagi para pembaca dan peneliti lainnya. Peneliti ingin memberikan saran kepada pembaca atau peneliti lainnya yang ingin mengembangkan penelitian dengan judul yang sama sebagai berikut : 
1. Penelitian yang dilakukan oleh peneliti diharapkan dapat membantu program studi sistem informasi dalam melakukan pekerjaan terutama dibagian jurnal mahasiswa.

2. Aplikasi sistem informasi e- jurnal ini dapat dikembangkan lebih lanjut, sehingga informasi yang disajikan dapat lebih jelas, lebih lengkap, lebih banyak agar menjadi suatu sistem informasi secara lengkap.

3. Aplikasi ini dapat dikembangkan lagi untuk cakupan yang lebih luas dan dapat diterapkan pada prodi laiin yang ada pada universitas islam indragiri (UNISI).

4. Peran aktif admin sangat diperlukan untuk memperbaharui ( update) informasi jurnal dan admin merevisi jurnal yang mahasiswa buat dan kirim kedalam sistem.

\section{Daftar Pustaka}

[1] Angriswono ennike dkk. sistem informasi perawatan pada praktik gigi ingnawati.

[2] Djaelangkara.Recky T.2015. Perancangan Sistem Informasi Akademik Sekolah Berbasis Web Studi kasus Sekolah Menengah Atas Kristen 1 Tomohon.

[3] Hariadi.Fajar.dkk.2013. Pembuatan Sistem Informasi perpustakaan Pada SDN sukoharjo pacitan berbasis web.

[4] Jogianto.2009. Sistem Teknologi Informasi. Yogyakarta : Andi

[5] Khairil.dkk.2012. Pembuatan E-Library madrasah Aliyah Negeri(MANArga Makmur Menggunakan Macromedia Dreamweaver.

[6] Mustaqbal.M.Sidi.dkk.2015. Pengujian aplikasi Menggunakan Black Box dan testing Boundary Value Analisis( Studi Kasus : Aplikasi Prediksi Kelulusan SNMPTN).

[7] Priyanti.Dewi.dkk.2013. Sistem Informasi Data Penduduk Pada Desa Bogoharjo Kecamatan Ngadirojo Kabupaten Pacitan.

[8] Zefriyenni.Ir.dkk.2015. Sistem informasi penjualan dan pengendalian persedian barang menggunakan metode economic order Quantity (EOQ) menggunakan Bahasa Pemrograman Java Dan Database My Sql pada toko kansa elpiji. 